\title{
TEKNIK PELAKSANAAN PROGRAM SAHABAT PERPUSTAKAAN DI SMA NEGERI 1 GUNUNGHALU KAB. BANDUNG BARAT
}

\author{
Dede Hani $\mathrm{R}^{1}$, Dian Sinaga ${ }^{2}$, Evi Rosfiantika ${ }^{3}$ \\ ${ }^{1,2,3}$ Program Studi Ilmu Informasi dan Perpustakaan Fikom Unpad \\ 1'dede11006@mail.unpad.ac.id, ${ }^{2}$ dian.sinaga@unpad.ac.id, ${ }^{3}$ evi.rosfiantika@unpad.ac.id
}

\begin{abstract}
This study discusses the Design of "Library Friend" Program in the School Library Development at the Library of SMA Negeri 1 Gununghalu. The purpose of this study is to determine human resource management, the activities and techniques of "Library Friend" program implementation. The method used is a qualitative method of action research. The data were collected by interview, observation, library research and the collection of documentation. The Informants in this study are the coordinator of the library, library staff, teachers, and the students of SMAN 1 Gununghalu. The members involved in the program are the students and the library staff. The activities of the program are making competitions, such as: reading poetry competition, scientific work competition, storytelling, writing Sundanese short stories contest (culture), and an exhibition of the library. The technical implementation of the Library Friend program will have several stages of implementation such as: socialization, counseling together, inauguration, work-meeting, the implementation of activities, job evaluation and work reports of the Library Friend program.
\end{abstract}

Keywords: School Library, "Library Friend" Program, School Library Development

ABSTRAK - Penelitian ini membahas Desain Program "Perpustakaan Teman" dalam Pengembangan Perpustakaan Sekolah di Perpustakaan SMA Negeri 1 Gununghalu. Tujuan dari penelitian ini adalah untuk menentukan manajemen sumber daya manusia, kegiatan dan teknik pelaksanaan program "Perpustakaan Teman". Metode yang digu- nakan adalah metode kualitatif penelitian tindakan. Data dikumpulkan melalui wawancara, observasi, studi pustaka dan pengumpulan dokumentasi. The Informan dalam penelitian ini adalah koordinator perpustakaan, staf perpustakaan, guru, dan siswa SMAN 1 Gununghalu. Anggota yang terlibat dalam program ini adalah mahasiswa dan staf perpus- takaan. Kegiatan dari program ini membuat kompetisi, seperti: kompetisi membaca puisi, lomba karya ilmiah, cerita, menulis Sunda cerita lomba pendek (budaya), dan pameran perpustakaan. Teknis pelaksanaan program Teman Perpustakaan akan memiliki beberapa tahapan implementasi seperti: sosialisasi, konseling bersama-sama, peresmian, pertemuan, pelaksanaan kegiatan, evaluasi pekerjaan dan laporan kerja dari program Perpustakaan Teman.

Kata kunci: Perpustakaan Sekolah, Program "Perpustakaan Teman", Pembangunan Perpustakaan Sekolah

\section{PENDAHULUAN}

Sahabat perpustakaan atau "Library Friends" di negara lain seperti Amerika sudah menjadi salah satu kegiatan atau wadah yang menjadi tempat berkumpulnya masyarakat atau orang-orang tertentu yang peduli terhadap perpustakaan. Anggota yang terlibat dalam sahabat perpustakaan ialah orang-orang atau masyarakat yang memang sangat peduli terhadap kegiatan-kegiatan dalam perpustakaan. Di Indonesia sendiri sahabat perpustakaan sudah ada beberapa yang menerapkan di beberapa perpustakaan, seperti Perpustakaan Perguruan Tinggi dan Sekolah Dasar.

Dalam hal ini peneliti berencana akan mengadaptasi program serupa yaitu "Sahabat Perpustakaan" sebagai salah satu kegiatan yang menjadi program dalam penelitian. Program ini sebelumnya belum ada di tempat penelitian, maka dari itu peneliti berharap dapat membuat rancangan 
program sahabat perpustakaan dengan siswa maupun staf yang berada di sekolah.

Anggota yang masuk program, sebelumnya telah mendapatkan seleksi terlebih dahulu atau rekomendasi dari pihak maupun guru di sekolah, seleksi ini dilakukan untuk menghindari perekrutan anggota yang tidak sesuai, karena peneliti ingin mendapatkan anggota yang benar-benar memiliki misi yang sama dengan peneliti yaitu sama-sama ingin mengembangkan perpustakaan dan menjadi salah satu orang yang lebih dulu mengetahui keberadaan serta pemanfaatan informasi yang sesuai dengan pencari informasi (pengguna), serta program sahabat perpustakaan ini dapat mem- berikan motivasi pada anggota agar bisa mem- berikan solusi informasi bagi para siswa lainnya untuk menjadikan perpustakaan sebagai tempat sumber belajar mereka.

Kegiatan sahabat perpustakaan merupakan kegiatan yang dapat membentuk siswa dalam mengembangkan kemampuan Soft Skill siswa dalam berorganisasi yang dapat dijadikan kegiatan diluar intrakulikuler. kegiatan yang dapat memberikan pengetahuan kepada siswa melalui kegiatan pengolahan perpustakaan sekolah.

Program sahabat perpustakaan merupakan ide peneliti dalam pemecahan masalah yang ada di Perpustakaan SMA Negeri 1 Gununghalu. Program sahabat perpustakaan ini bukanlah program baru yang peneliti buat sendiri, melainkan program yang telah lama dibuat oleh perpustakaan-perpustakaan yang berada di Amerika. Peneliti merasa ingin mengaplikasikan program serupa namun dalam ranah atau lingkungan sekolah seperti yang saat ini sedang peneliti lakukan. Program sahabat perpus- takaan yang mana belum di kenal dan digunakan ini akan membuat terobosan baru dalam perpustakaan mengenai penelitian yang menggunakan program sahabat perpustakaan dalam pemecahan masalah yang berada di sekolah.

Pada dasarnya remaja atau siswa yang berada didalam sekolah akan lebih menyenangi hal-hal yang dilakukan oleh temannya terlebih dahulu. Dengan adanya rancangan sahabat perpustakaan dari peneliti, maka sangat diharapkan program ini dapat berjalan dengan sesuai. Dengan siswa sebagai sasaran dari program maka siswa akan mengalami dan merasakan bagaimana cara mengelola atau mengenal dunia perpustakaan secara lebih detail. Mulai dikenalkan dengan hal-hal yang umum seperti, apa perpustakaan, tujuan dan fungsi perpustakaan, jenis perpustakaan, dan hal-hal lainnya yang meliputi perpustakaan.

SMA Negeri 1 Gununghalu yang berada di Kabupaten Bandung Barat tepatnya berada di Jl. Simpang Gununghalu, Kecamatan Gununghalu. Merupakan salah satu sekolah yang sudah memiliki perpustakaan sebagai sumber belajar untuk para siswa. Pihak sekolah menilai perpustakaan merupakan tempat yang penting bagi para siswanya dalam menunjang pengetahuan dan pembelajaran. Maka dari itu, pihak-pihak di dalam sekolah menjadikan perpustakaan sebagai salah satu sumber belajar di lingkungan sekolah, meskipun pada saat ini perpustakaan yang ada tidak sepenuhnya berjalan secara efektif. Namun apabila dilihat dari fungsinya sendiri perpustakaan SMA Negeri 1 Gununghalu ini belum sepenuhnya 
efektif atau kurangnya pengelolaan, pemanfaatan serta pengembangan didalamnya.

Layanan yang diberikan kepada pengguna perpustakaan belum efektif karena perpustakaan hanya dikelola oleh seorang pustakawan. Perpustakan sempat membuat promosi untuk menarik pengunjung atau siswa yang datang, namun hanya sebatas himbauan atau tugas yang dilakukan ketika guru menyuruh siswa untuk datang ke perpustakaan sebagai pengganti belajar di kelas. Belum adanya rasa kesadaran dan minimnya pengetahuan tentang perpustakaan dari siswa sendiri.

Perpustakaan SMA Negeri 1 Gununghalu memiliki seorang staf yang bekerja, dengan latar belakang pendidikan ilmu perpustakaan. Tentunya ini sudah menjadi nilai lebih dari perpustakaan sekolah karena telah memiliki seorang staf yang sudah memiliki dasar serta pengetahuan dan keahlian tentang perpustakaan. Sehingga akan sangat membantu dalam pengembangan perpustakaan dengan melihat latar belakang pendidikan yang dimiliki oleh staf perpustakaan.

Melihat kurangnya pengembangan dalam perpustakaan sekolah maka dibutuhkan beberapa tindakan pengelolaan maupun pengembangan yang dapat menarik minat siswa serta keberadaan dan manfaat atau kegunaan dari perpustakaan. Tindakan yang dilakukan merupakan tindakan yang dapat memecahkan permasalahan dalam lingkungan perpustakaan sekolah. Maka dari itu peneliti memiliki ide untuk membuat sebuah program dengan nama "Sahabat Perpustakaan" sebagai program penelitian di SMA Negeri 1 Gununghalu.
Peneliti melihat adanya kesempatan untuk melakukan rancangan Sahabat Perpustakaan di SMAN 1 Gununghalu. Dari beberapa hasil observasi lapangan sebelumnya yang telah peneliti lakukan. Rancangan yang dibuat merupakan bentuk keprihatinan peneliti terhadap kondisi perpustakaan. Penggunaan perpustakaan menurut guru dan staf perpustakaan dan beberpa siswa masih belum terlihat optimal. Perpustakaan digunakan hanya pada saat siswa datang ke perpustakaan karena diperintahkan oleh guru untuk pindah belajar ke perpustakaan jika gurunya tidak dapat hadir di kelas, selebihnya siswa tidak dengan rasa kesadaran maupun keinginan untuk mengunjungi ke perpustakaan dengan sendirinya tanpa perintah pengalihan belajar dari guru.

\section{TINJAUAN PUSTAKA}

Perpustakaan sekolah adalah perpustakaan yang ada di lingkungan sekolah. Diadakannya perpustakaan sekolah adalah untuk tujuan memenuhi kebutuhan informasi bagi masyarakat di lingkungan sekolah yang bersangkutan, khususnya para guru dan murid. (Yusup 2010, 2)

Penyelenggaraan perpustakaan sekolah itu sendiri mengacu kepada Undang- Undang Nomor 2 Tahun 1989 tentang Sistem Pendidikan Nasional. Dimana pada Pasal 35 undang-undang tersebut dikemukakan bahwa setiap satuan pendidikan jalur pendidikan sekolah, baik yang diselenggarakan oleh pemerintah maupun oleh masyarakat, harus menyediakan sumber-sumber belajar. (Yusup 2010, 2)

Dari uraian diatas mengenai pasal 35 yang menyebutkan bahwa sebuah satuan pendidikan jalur pendidikan sekolah, harus menyediakan sumber-sumber belajar. Salah satu contoh 
sumber-sumber belajar yang diyakini paling ideal adalah perpustakaan tentunya ini hanya merupakan salah satu sumber-sumber belajar. Hanya saja apabila dilihat dari fungsinya memang perpustakaanlah yang paling tepat menjadi sumber-sumber belajar bagi penunjang kebutuhan informasi maupun pendidikan yang ada di lingkungan sekolah menurut penulis.

Namun tidak sedikit sekolah yang menjadikan perpustakaan sebagai sumber-sumber belajarnya, tapi apakah perpustakaan tersebut sudah benar menjalankan fungsinya sebagai sumber belajar atau tidak. Sepertinya masih banyak juga sekolah yang hanya menjadikan perpustakaan sebagai fasilitas atau tempat yang hanya dijadikan sebagai bagian dari kebutuhan atas perintah atau formalitas semata. Padahal jika dilihat dari kegunaannya dan manfaatnya perpustakaan merupakan bagian terpenting dalam sebuah pendidikan khususnya dalam pendidikan sekolah yang mana dapat membentuk karakter pelajar atau siswa dalam membaca dan mengembangkan pengetahuannya sejak sekolah atau masa-masa dalam pendidikannya.

Dengan program sahabat perpustakaan sebagai program yang di lakukan dalam penelitian tindakan (action research) yang berjudul "Rancangan Program Sahabat Perpustakaan Dalam Pengem- bangan Perpustakaan Sekolah”, dengan sub judul "Penelitian Tindakan Rancangan Program Sahabat Perpustakaan di SMA Negeri 1 Gununghalu Kabupaten Bandung Barat" dengan tujuan agar perpustakaan yang awalnya kurang berkembang menjadi berkembang dengan adanya penelitian serta program dari penelitian.

\section{METODE PENELITIAN}

Penelitian merupakan suatu proses atau kegiatan yang dilakukan oleh seseorang atau kelompok secara bertahap untuk mendapatkan hasil dari suatu permasalahan dalam penelitian. Proses yang dilakukan dalam sebuah penelitian harus sesuai dengan prosedur atau tahapannya sehingga satu sama lain saling terintegrasi, agar penelitian yang dilakukan memiliki bobot dan mempunyai tahapan serta prosedur yang tepat dan dapat memberikan kesimpulan-kesimpulan yang tidak meragukan.

Dalam penelitian mengenai rancangan program sahabat perpustakaan, peneliti menggunakan penelitian tindakan. Reason \& Bradbury (2001) dalam Madya (2007) menyebutkan bahwa:

Penelitian tindakan adalah proses partisipatori, demokratis yang berkenaan dengan pengembangan pengetahuan praktis mencapai tujuan-tujuan mulia manusia, berlandaskan pandangan dunia partisipatori yang muncul pada momentum historis sekarang ini. Ia berusaha memadukan tindakan dengan refleksi, teori dengan praktik, dengan menyertakan pihak-pihak lain, untuk menemukan solusi praktis terhadap persoalan-persoalan yang menyesalkan, dan lebih umum lagi demi pengembangan individu-individu bersama komunitasnya. (Madya 2007, 11)

Penelitian tindakan pada umumnya cenderung jarang digunakan karena dianjurkan digunakan oleh tenaga pendidik yang kebanyakan tidak memiliki keberanian untuk melakukan penelitian. Karena jenis penelitian tindakan ini jarang kita temui sehingga orang biasa dalam membedakan penelitian, penelitian tersebut ialah antara riset tindakan dengan riset kulitatif dan 
kuantitatif. Menurut Tomal (2003) dalam Suparno (2008) "riset tindakan berbeda dengan riset kualitatif dan kuantitatif, tetapi mempunyai sifat keduanya. Riset tindakan lebih menekankan proses pemecahan persoalan dan membuat kemajuan dari persoalan yang dihadapi" (Suparno 2008, 9). Namun dalam penyajiannya riset tindakan boleh menggunakan pendekatan dengan riset keduanya yaitu kualitatif dan kuantitatif, dan hal tersebut tidak terlalu ketat dan dapat diaplikasikan.

Pengumpulan data dilakukan dengan menggunakan teknik wawancara, observasi, studi pustaka dan pengumpulan dokumentasi. Triangulasi data juga dilakukan untuk menghasilkan data sebagai pembanding dalam penelitian yang dilakukan.

\section{HASIL DAN PEMBAHASAN}

Teknis pelaksanaan program sahabat perpustakaan merupakan tata cara pelaksanaan dalam program sahabat perpustakaan. Dibuat untuk mempermudah dalam pelaksanaan program dalam sekolah. Teknis pelaksanaan ini akan membantu pihak perpustakaan maupun siswa yang akan terlibat didalam program, mulai diketahuinya siapa yang bertanggung jawab dalam program, sampai nanti bagaimana tata cara pelaksaan program sahabat perpustakaan yang akan dilaksanakan di dalam sekolah.

Rancangan program sahabat perpustakaan akan terasa resmi atau legal keberadaanya jika ada seseorang atau pembina dalam program. Pembinaan yang diberikan kepada anggota sahabat perpustakaan salah satunya dengan memperhatikan keberadaannya dan memberikan pengarahan kepada anggota sahabat perpustakaan. Koordinator perpustakaan dipilih sebagai penanggung jawab yang tepat karena program ini melibatkan perpustakaan sebagai dasarnya. Maka dari itu, pihak-pihak yang terlibat didalam perpustakaan akan sangat diharapkan keberadaannya dalam proses terlaksananya program sahabat perpustakaan.

Sahabat perpustakaan di rancang untuk membantu perpustakaan, bantuan yang diberikan berupa bantuan-bantuan yang nantinya diharapkan dapat meningkatkan perkembangan dalam perpustakaan sekolah. Teknis pelaksaan dalam program sahabat perpustakaan dilakukan untuk memberikan batasan atau job desck bagi para anggota sahabat perpustakaan. Memberikan kebebasan dalam menyampaikan ide atau perkembangan terhadap perpustakaan. Anggota sahabat perpustakaan disusun secara rinci kegiatan dan kewajiban mereka dalam keanggotaan.

\section{Sosialisasi sahabat perpustakaan}

Sosialisasi yang dilakukan dalam sahabat perpustakaan adalah pengenalan dan pemberitahuan apa itu sahabat perpustakaan, tujuan sahabat perpustakaan, dan manfaat dari program sahabat perpustakaan kepada siswa. Sosialisasi dilakukan dengan cara mendatangi setiap kelas X dan XI guna memberikan pemahaman terhadap sahabat perpustakaan kepada para siswa.

Seperti yang telah diungkapkan oleh Bapak Ruslan dalam wawancara, beliau memberikan saran mengenai sosialisasi sahabat perpustakaan tersebut melalui tindakan langsung ke kelas-kelas.

Sosialisasi yang dilakukan dalam sahabat perpustakaan adalah pengenalan dan pemberitahuan apa itu sahabat perpustakaan, tujuan sahabat perpustakaan, dan manfaat dari program sahabat 
perpustakaan kepada siswa. Sosialisasi dilakukan dengan cara mendatangi setiap kelas X dan XI guna memberikan pemahaman terhadap sahabat perpustakaan kepada para siswa.

Ada beberapa hal yang harus dilakukan didalam sosialisasi yang dilakukan di Program Sahabat Perpustakaan diantaranya sebagai berikut:

1. Melakukan kajian pembahasan penyampaian sosialisasi apa saja yang akan di sampaikan dalam sosialisasi sahabat perpustakaan.

2. Siapkan materi penyampaian sosialisasi sahabat perpustakaan seperti: (Pengertian dari apaitu Sahabat Perpustakaan, tujuan sahabat perpustakaan, manfaat sahabat perpustakaan, kegiatan sahabat perpustakaan)

3. Penyampaian sosialisasi dilakukan oleh pihak dari sekolah terlebih dahulu khususnya pada pihak bagian perpustakaan (pembina langsung dari program sahabat perpustakaan)

4. Sasaran sosialisasi program sahabat perpustakaan merupakan siswa yang duduk dikelas X dan XI.

5. Cara yang dilakukan dalam sosialisasi Sahabat Perpustakaan menggunakan cara sosialisasi langsung mendatangi masingmasing kelas ataupun dengan cara mengundang siswa ke perpustakaan.

Tahapan sosialisasi yang digunakan merupakan tahapan yang digunakan pada program sahabat perpustakaan. Sosialisasi merupakan kegiatan pengenalan dan penyampaian Program sahabat Perpustakaan kepada sasaran anggota yaitu siswa. Siswa diberitahukan program guna memberikan pemahaman dan menarik minat siswa terhadap program yang akan dilakukan didalam perpustakaan.

Tujuan dari sosialisasi ini ialah untuk memberikan semua informasi dan pengenalan program kepada siswa melalui tindakan sosialisasi langsung datang memberikan pengarahan mengenai program sahabat perpustakaan. Siswa akan lebih memahami langsung dan secara sadar mengerti sebelumnya mengenai program, pemahaman tersebut akan menjadi bekal siswa bila nantinya akan ikut bergabung dalam sahabat perpustakaan.

\section{Bimbingan/ Penyuluhan Bersama Sahabat Perpustakaan}

Ada beberapa fase pelatihan menurut Nawawi (2003) fase-fase tersebut ialah sebagai berikut:

a. Fase Perencanaan

Fase ini dimulai dengan menetapkan tujuan pelatihan, berisi tentang "apa yang perlu dipelajari".

b. Fase mendesain pelatihan

Melakukan metode dan teknik pelatihan dengan cermat, menyusun materi dengan benar sistematik,

c. Fase evaluasi kegiatan pelatihan

Kegiatan menilai kegiatan pelatihan yang telah dilaksanakan. (Nawawi 2003, 228-229)

Bimbingan yang diberikan kepada sahabat perpustakaan akan diberikan langsung kepada mereka yaitu para anggota oleh pembina dari sahabat perpustakaan. Bimbingan dimaksudkan untuk memberikan pemahaman lain seputar perpustakaan dan detail alur kerja para anggota dari 
sahabat perpustakaan. Bimbingan ini bersifat pemberian pemahaman setiap harinya kepada para anggota sahabat perpustakaan agar mereka lebih mengenal dan mengetahui informasi mengenai perpustakaan dan memperbaiki serta melatih kemapuan pada diri anggota sahabat perpustakaan.

Pemberian informasi perpustakaan dimaksudkan untuk mengetahui komponen-komponen apa saja yang terdapat didalam perpustakaan. Siswa pada umumnya tidak akan mengetahui secara keseluruhan maupun detail mengenai perpustakaan. Maka dari itu bimbingan disini dibuat untuk memberikan informasi-informasi dan kegiatan didalam perpustakaan. Seperti misalnya memberikan pemahaman perpustakaan mengenai: Definisi perpustakaan, tujuan perpustakaan, manfaat perpustakaan, jenis-jenis perpustakaan, layanan perpustakaan, dan informasi lain terkait kajian ilmu perpustakaan. Bimbingan yang dilakukan bisa dipimpin oleh Pembina dari program.

Pemberian bimbingan atau pelatihan pada anggota sahabat perpustakaan merupakan pemberian kemampuan melalui tahapan-tahapan apa saja yang akan dilakukan dalam program, jadi dalam bimbingan siswa akan diberikan kemampuan dan pemahaman seputar perpustakaan beserta kegiatan sahabat perpustakaan.

\section{Pelantikan}

Penerimaan merupakan istilah seleksi yang ada didalam manajemen sumber daya manusia. penerimaan yang dimaksud disini merupakan penerimaan anggota sahabat perpustakaan. Penerimaan dilakukan sebgai bukti sah yang telah dilakukan bahwa anggota yang sudah mengikuti sahabat perpustakaan.
Setelah melakukan penerimaan hendaknya membuat sebuah pelantikan, pelantikan disini merupakan sebuah pelantikan bukti keikutsertaan para anggota dan merupakan ciri apresiasi dari pelaksana kepada para anggota sahabat perpustakaan yang telah terlibat dalam program. Pelantikan akan diberikan kepada para anggota sahabat perpustakaan dengan mensahkan anggota dan juga program sahabat perpustakaan sebagai kegiatan baru yang ada di dalam perpustakaan.

Pelantikan bagi para siswa yang terlibat akan ditandai dengan pemberian syal atau pin maupun penanda lainnya yang diberikan untuk menjadi pembeda anggota dari siswa lainnya yang tidak ikut terlibat didalam program sahabat perpustakaan. Selain mereka telah sah menjadi bagian dari program dan perpustakaan, mereka akan diberikan kebebasan untuk berpendapat dan ikut terlibat dalam kegiatan perpustakaan.

Pemberian penanda kepada anggota sahabat perpustakaan merupakan ciri dari keberadaan anggota yang berada dilingkungan sekolah. Menjadi pembeda dengan siswa lainnya. Hal ini akan menimbulkan ketertarikan siswa yang lainnya karena mereka berbeda dengan siswa lainnya. Hal ini akan menjdai nilai positif bagi perpustakaan dan program.

\section{Rapat kerja sahabat perpustakaan}

Rapat kerja sahabat perpustakaan merupakan kegiatan yang akan diatur dan dilaksanakan oleh anggota sahabat perpustakaan. Dengan pengamatan serta pengarahan dari pembina sahabat perpus- takaan, maka rapat kerja sahabat perpustakaan merupakan bagian dari program untuk mengetahui bagaimana cara kerja dan kegiatan pertemuan yang dilakukan oleh anggota. 
Rapat kerja sahabat perpustakaan dilakukan di setiap minggu.

Sahabat perpustakaan dituntut membuat rapat kerja untuk perkembngan kegiatan maupun program didalamnya. Rapat kerja selain untuk mengetahui kegiatan atau pekerjaan apa saja yang akan dilakukan oleh anggota, juga sebagai bentuk pendekatan setiap anggota, anggota kepada anggota, anggota kepada pembina begitupun sebaliknya. Kedekatan antar anggota dan pembina didalam suatu program sangatlah penting. Mereka diberikan kebebasan dalam berekspresi maupun didalam memberikan pemikiran didalam kegiatan maka mereka perlu mendekatkan diri melalui kegiatan rapat maupun dalam hal lainnya.

\section{Pelaksanaan kegiatan sahabat perpustakaan}

Pelaksanaan kegiatan sahabat akan melibatkan sahabat perpustakaan sebagai panitia maupun penyelenggara dalam kegiatan. Pelaksanaan kegiatan yang akan dilaksanakan berdasarkan hasil keputusan maupun pengajuan yang diberikan oleh anggota sahabat perpustakaan.

\section{Evaluasi kerja sahabat perpustakaan}

Evaluasi hasil kerja sahabat perpustakaan dibuat untuk mencari tahu bagaimana hasil kerja yang telah dilakukan oleh sahabat perpustakaan, upaya-upaya yang telah dilakukan guna membantu pengembangan perpustakaan. Evaluasi akan dilihat dari hasil kerja anggota sahabat perpustakaan selama terbentuk.

Evaluasi sahabat perpustakaan merupakan bentuk dari pencapaian yang telah dilakukan apa saja. Evaluasi ini dilakukan oleh pihak sekolah, pembentukan program sahabat perpustakaan merupakan solusi pengembangan terhadap perpustakaan. dalam setiap kegiatan dalam sahabat peprustakaan perlu adanya evaluasi sebagai pembelajaran bagi tahapan selanjutnya dalam program.

\section{Laporan kerja sahabat perpustakaan.}

Anggota sahabat perpustakaan di wajibkan memberikan laporan kerjanya kepada pembina sahabat perpustakaan seminggu sekali setelah rapat kerja terlaksana. Laporan kerja yang dibuat dan diberikan kepada pembina untuk mendapatkan hasil dan pengetahuan yang telah dilakukan selama sahabat perpusatakaan berlangsung.

Laporan kerja lainnya ialah dengan membukukan dan mengagendakan setiap kegiatan sahabat perpustakaan berlangsung. Laporan kerja dalam bentuk lainnya bisa disebut sebagai laporan pertanggung jawaban dari sahabat perpustakaan.

Penting adanya laporan dari sahabat perpustakaan dalam setiap kegiatannya. Karena dalam suatu kegiatan memerlukan sebuah laporan yang didalamnya dapat membantu program selanjutnya dalam peprpustakaan maupun keberlangsungan program dimasa regenerasi selanjutnya.

Dalam sebuah program sebaiknya kita memperhatikan beberapa teknis yang akan dilakukan di dalam program, diatas telah dipaparkan beberapa teknis pelaksanaan yang akan dilaksanakan dalam sebuah program sahabat perpustakaan di SMAN 1 Gununghalu. Mejeleskan setiap detail dari teknis pelaksanna yang akan dilakukan. Adapun penjelasan mengenai pelaksanaan program yang dipaparkan oleh Siagian (2103):

Perlu ditekankan bahwa sesungguhnya penyelenggaraan program pelatihan dan pengembangan sangat situasional sifatnya. 
Oleh karena itu tepat tidaknya suatu teknik mengajar digunakan sangat tergantung pada berbagai pertimbangan yang ingin ditonjolkan, seperti kehematan dalam pembiayaan, materi program,tersedianya fasilitas tertentu, preferensi dan kemampuan peserta, preferensi dan kemampuan pelatih dan prinsip-prinsip belajar yang hendak diterapkan. (Siagian 2013, 191-192)

Dalam sebuah pelaksanaan program pengembangan sebaiknya kita melihat kondisi dari para peserta dan juga pelatih. Menentukan dan mempertimbangkan hal-hal pembiayaan dan bagaimana penyampaian materi yang akan diberikan kepada anggota. Hal ini tentunya akan menjadi salah satu acuan bagi terciptanya suatu pelaksanaan program yang akan dicapai.

\section{SIMPULAN}

Teknis pelaksanaan program sahabat perpustakaan di rancang untuk mempermudah tata pelaksanaan program, menggunakan alur serta teknis yang sebaiknya dilakukan di dalam program sahabat perpustakaan. Teknis pelaksanaan tersebut ialah sebagai berikut, Teknis pelaksanaan program sahabat perpustakaan terdapat beberapa tahapan pelaksanaan yang dilakukan, tahapan tersebut ialah sosialisasi sahabat perpustakaan,bimbingan/ penyuluhan bersama sahabat perpustakaan, pelantikan, rapat kerja sahabat perpustakaan, pelaksanaan kegiatan sahabat perpustakaan, evaluasi kerja sahabat, laporan kerja sahabat perpustakaan.

\section{DAFTAR PUSTAKA}

Kahar, Irawaty A. (2009). Pola Strategi Sinergis Pengembangan Perpustakaan Sekolah.
Diakses melalui Jurnal Tabularasa PPS UNIMED Vol. 6 No. 2. Dalam digilib.unimed.ac.idpublicUNIMED-Article-2 4598-Irawaty.pdf. pada tanggal 27 Februari 2015 pukul 11.12 WIB

Madya, Suwarsih. (2007). Teori dan Praktik Penelitian Tindakan. Bandung: IKAPI

Moleong, Lexy J. (2007). Metode Penelitian Kualitatif. Bandung: Rosdakarya

Nawawi, Hadari. (2003). Manajemen Sumber Daya Manusia. Yogyakarta: Gadjah Mada University Press

Siagian, P. Sondang. (2013). Manajemen Sumber Daya Manusia. Jakarta: Bumi Aksara

Sinaga, Dian. (2005). Perpustakaan Sekolah. Jakarta: Kreasi Media Utama

Suparno, Paul. (2008). Riset Tindakan Untuk Pendidikan. Jakarta: PT. Grasindo

Yusup, M. Pawit. (2010). Pedoman

Penyelenggaraan Perpustakaan Sekolah.

Jakarta: Kencana Prenada Media Group 
